\title{
The Misconceived Search for the Meaning of "Speech" in Freedom of Speech
}

\author{
Larry Alexander \\ University of San Diego School of Law, San Diego, USA \\ Email: larrya@sandiego.edu
}

Received 2 January 2015; accepted 20 January 2015; published 23 January 2015

Copyright (C) 2015 by author and Scientific Research Publishing Inc. This work is licensed under the Creative Commons Attribution International License (CC BY). http://creativecommons.org/licenses/by/4.0/

(c) (i) Open Access

\begin{abstract}
In this (very) short essay, I establish these points: All speech is symbolic; any conduct can be used to communicate a message (i.e., symbolically); government's purpose in regulating, and not a speaker's intention to communicate, defines the realm of freedom of expression; and determining the value of speech has a denominator problem.
\end{abstract}

\section{Keywords}

Speech, Symbolic Speech, Low Value Speech, Governmental Purpose

\section{Introduction}

There have been and continue to be numerous law review articles and judicial opinions debating whether something is or is not "speech" within the meaning of freedom of speech. Benjamin and Wu debate whether computer code is "speech" in the relevant sense (Benjamin, 2013; Wu, 2013). Calvert analyzes whether tattoos and tattooing, "Likes" and "Liking" on Facebook, and begging are "speech" in the relevant sense (Calvert, 2013). Sixtyseven years ago the Supreme Court decided, over dissents, that movies were speech (Winters v. New York, 1948). And almost fifty years ago the court distinguished "speech" from "symbolic speech", concluding that the latter was due less constitutional protection than the former (United States v. O'Brien, 1968).

These debates are misconceived. All speech is symbolic. That is, there is no category of non-symbolic speech. Conversely, any token of conduct can be employed to symbolize an idea, a word, a syllable, or a letter. Any conduct can constitute a communicative code. Making marks and uttering sounds are common forms of employing symbols to communicate. But smoke signals, semaphore flags, facial expressions, and an almost infinite variety of other conduct can be employed as communicative symbols. Shooting the mailman may be an effective way of conveying the thought that one is fed up with the mail service. Covering oneself with chocolate may be an effective way of spoofing performance art, and so on. 
Because all speech is symbolic, and because any conduct can be used as a communicative symbol, asking whether computer code or tattoos are or are not speech is misconceived ${ }^{1}$.

What about speaker's intent? Can we distinguish conduct that is speech from conduct that is not by reference to whether those engaged in the conduct intended thereby to send a message? In a word, no. The person who shoots the mailman does not raise a free speech issue — even a losing one—by claiming, sincerely, that he did so to protest the mail service. Similarly for someone who rehearses his lines in a play in his apartment in a loud voice that comes across as unintelligible and irksome noise to the other tenants. Conversely, even where there is no speaker, and thus no speaker's intent, a free speech claim may rightly lie. If the pounding of waves on the rocks has left the marks "Throw the rascals out", and government closes off the beach to prevent people from seeing those marks and taking their "message" to heart-perhaps they will think this is a message from Godthen I would submit that the government is doing what freedom of speech forbids. It is likewise doing what freedom of speech forbids if it forbids a certain line of research-say, into racial differences in intelligence -because it fears the message that the findings might convey, even though the researchers are not intending to send any message by conducting the research ${ }^{2}$. And a fortiori, the same is true when there is a speaker, but the speaker has no constitutional rights—as when the speaker is dead or is a foreigner. Karl Marx's writings come within freedom of speech even though he is both dead and foreign - at least if the government suppresses them because of the ideas Marx expressed.

The only proper basis for a free speech claim is whether government is attempting to prevent an audience from receiving certain ideas. That is why message-based suppression of speech is central. But message-based suppression is central no matter what symbols are employed to express the content. If computer code is regulated to suppress ideas, that is a free speech issue. If it is regulated for other reasons, that is not a free speech issue. If tattoos are regulated to suppress ideas the tattoo artist is attempting convey, or the ideas the one tattooed is attempting to convey, free speech is in play. But if tattoos are regulated for reasons of health, say, and irrespective of the ideas they are conveying, free speech is not in play.

When I say free speech is not in play if government is not regulating symbols to suppress the receipt of certain ideas, I am ruling out of free speech's domain all content-neutral regulations, including so-called time, place, and manner regulations. Indeed, if people are forbidden to say "Gosh", not because of any idea conveyed thereby, but solely because Bill Gates owns the letter $G$ and has not granted permission use it, no free speech issue is present. That is a strong position, but it is a corollary of the position that free speech is in play when - and only when-government is regulating to prevent the receipt of an idea. Moreover, all content-neutral regulations - the entire corpus juris - have speech effects: they affect what gets said, by whom, to whom, and with what effect. And there is no viewpoint-neutral perspective that a court or any other governmental body can take on which speech effects should invalidate a content-neutral regulation and which should not ${ }^{3}$.

The upshot: Attempts to regulate the messages that people receive raise the issue of free speech (though they are not necessarily violations of free speech). Attempts to regulate the media through which speech is conveyed, unless for the purpose of regulating messages, raise no issue of free speech, a few derelict Supreme Court cases to the contrary notwithstanding ${ }^{4}$. This analysis exposes two errors the Supreme Court made in United States $v$. O'Brien (1968). The first was to deny that Congress's purpose in forbidding the destruction of draft cards was material to whether that statute violated freedom of speech. The second was to argue that even if the statute was really just the regulation of the medium of expression and not an attempt at suppressing a message, O'Brien would still have a free speech claim if he lacked adequate alternative means of conveying his message. The Court in subsequent cases admitted the materiality of government's purpose in regulating media of expression and thus corrected its first error ${ }^{5}$. It has never corrected the second error, which would presumably give free speech protection to one who paints his message on the wall of a government building, steals another's printing press, commandeers another's TV studio, or burns another's money (to protest inflation) so long as one has no

\footnotetext{
${ }^{1}$ Although this is not an essay seeking an originalist understanding of the First Amendment's meaning of "the freedom of speech", Eugene Volokh's research has, I believe, revealed that my analysis is at least not at odds with that meaning (Volokh, 2009).

${ }^{2}$ I owe this example to my colleague Dov Fox.

${ }^{3}$ This point is elaborated at length in chapter two of Alexander (2005).

${ }^{4}$ See, for example, Schneider v. State (1939) (striking down a ban on pamphleteering enacted to reduce littering) and International Society for Krishna Consciousness, Inc. v. Lee (1992) (striking down a restriction on distributing literature in an airport enacted to protect passengers from annoyance and delay).

${ }^{5}$ See, for example, Wayte $v$. United States (1985) (asserting the relevance of government's purpose to a first amendment claim) and Mt. Healthy City Board of Education v. Doyle (1977) (same). See generally Rubenfeld (2001) and Alexander (2005: ch. 3).
} 
equally effective means of reaching his intended audience with his message. I think it fair to surmise that the Court did not really mean what it said in O'Brien on this point, or that if it did, it will ignore what it said and render its error harmless.

\section{Addendum}

A related issue: Some free speech jurisprudence turns on the idea that some types of speech are "low value" speech, and that other types of speech lack any redeeming social value. (So-called "adult” books and movies are said to belong to the "low value” category (Young v. American Mini Theatres, Inc., 1976); hard-core pornography is said to belong to the "no value" category (Miller v. California, 1973; Roth v. United States, 1957)).

But there is a major problem with assigning value to types of speech, a problem analogous to the so-called “denominator" problem in takings jurisprudence. (That problem stems from the Supreme Court's making the determination of a regulatory taking turn on the effect of the regulation on the parcel taken as a whole, which seems arbitrary because both space and time can be infinitely divided or added to (Lucas v. South Carolina Coastal Council, 1992)).

The analog of the denominator problem for low and no-value speech can be easily illustrated ${ }^{6}$. Suppose a medical text in the public library is only looked at by people pruriently interested in its pictures of naked men and women. For its actual audience, it functions as pornography. On the other hand, suppose some hard-core porn-Debbie Does Dallas, say-is used in several college classrooms and research projects for the purpose of examining human sexual psychology, the sociology of deviant sexuality, or some other serious scholarly purpose. One might conclude that for purposes of determining the value of some speech token, one should use as the denominator the larger environment in which it occurs-much as one does not isolate its sexual descriptions from the rest of Lady Chatterley's Lover, or a steamy sex scene from a high-brow movie. In terms of the overall context, the medical text may be low or no value, whereas Debbie Does Dallas may be very high value.

Of course, once one appreciates that a speech token's value is a product of its broader context, we will see how hard it is to determine a speech token's value. Perhaps the scholarly research using Debbie Does Dalles will itself turn out to be valueless or even harmful. Perhaps the prurient use of the medical text will produce some unanticipated benefit. The contextual lens can be ever and ever widened spatially and temporarily, just as it can be narrowed to the sex scene within a high-brow book or movie.

The focus should be, not on the value of the speech type or token, but on why government is regulating what it is regulating.

\section{References}

Alexander, L. (1989). Low Value Speech. Northwestern University Law Review, 83, 547-554.

Alexander, L. (2005). Ch. 2: Freedom of Expression and Regulations that Affect Messages But are Not Enacted for That Reason. In Is There a Right of Freedom of Expression? (pp. 13-37). Cambridge: Cambridge University Press. http://dx.doi.org/10.1017/CBO9780511614668.003

Benjamin, S. M. (2013). Algorithms and Speech. University of Pennsylvania Law Review, 161, 1445-1494.

Calvert, C. (2013). Fringes of Free Expression: Testing the Meaning of "Speech” Amid Shifting Cultural Mores \& Changing Technologies. Southern California Interdisciplinary Law Journal, 22, 545-590.

International Society for Krishna Consciousness, Inc. v. Lee, 505 U.S. 830 (1992).

Lucas v. South Carolina Coastal Council, 505 U.S. 1003 (1992).

Miller v. California, 413 U.S. 15 (1973).

Mt. Healthy City Board of Education v. Doyle, 429 U.S. 274 (1977).

Roth v. United States, 354 U.S. 476 (1957).

Rubenfeld, J. (2001). The First Amendment's Purpose. Stanford Law Review, 52, 767-832. http://dx.doi.org/10.2307/1229492

Schneider v. State, 308 U.S. 147 (1939).

United States v. O’Brien, 397 U.S. 367 (1968).

Volokh, E. (2009). Symbolic Expression and the Original Meaning of the First Amendment. The Georgetown Law Journal,

\footnotetext{
${ }^{6}$ The following draws an earlier article of mine (Alexander, 1989).
} 
97, 1057-1084.

Wayte v. United States, 470 U.S. 598 (1985).

Winters v. New York, 333 U.S. 507 (1948).

Wu, T. (2013). Machine Speech. University of Pennsylvania Law Review, 161, 1495-1533.

Young v. American Mini Theatres, Inc., 427 U.S. 50 (1976). 
Scientific Research Publishing (SCIRP) is one of the largest Open Access journal publishers. It is currently publishing more than 200 open access, online, peer-reviewed journals covering a wide range of academic disciplines. SCIRP serves the worldwide academic communities and contributes to the progress and application of science with its publication.

Other selected journals from SCIRP are listed as below. Submit your manuscript to us via either submit@scirp.org or Online Submission Portal.
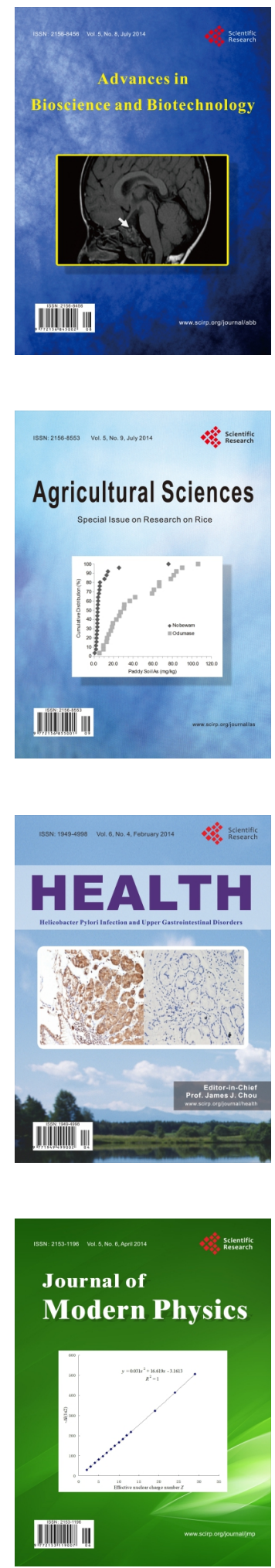
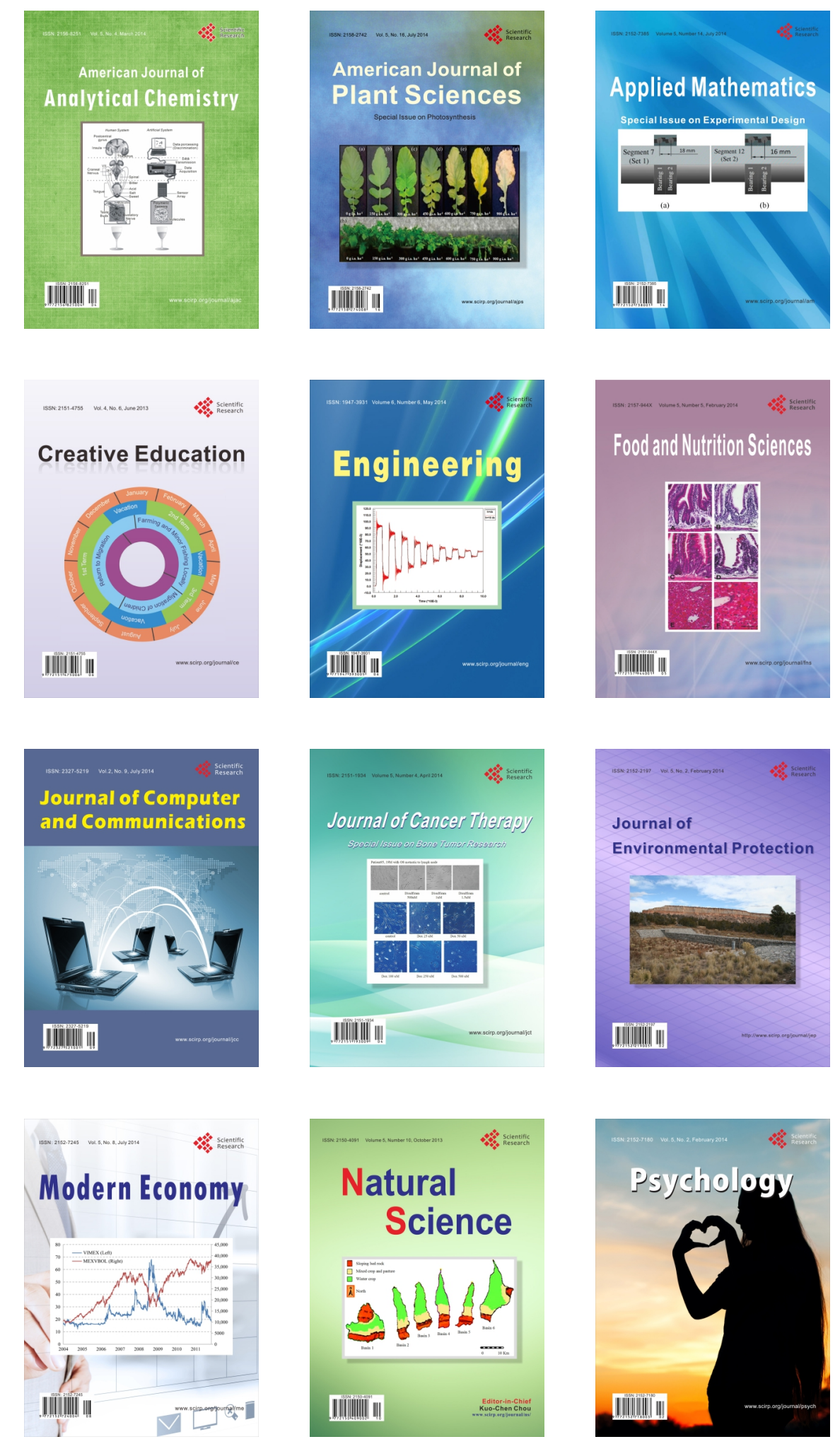